\title{
Exploration of the coefficients of correlation of different segmental measurements with total length of disarticulated femoral bones: a systematic review
}

\author{
KHANAL, L. *, SHAH, S. and KOIRALA, S. \\ Department of Anatomy, BP Koirala Institute of Health Sciences - BPKIHS, Post Box 56700, Dharan, Nepal \\ *E-mail: voicetolaxman@yahoo.co.in
}

\begin{abstract}
Introduction: In a forensic case with availability of femoral fragments, estimation of the total femoral length of the available segment is one of the steps used for estimating an inidividual's stature. This estimation will be more accurate if the segment has a high coefficient of correlation with the total length of the femur. This article reviews the coefficients of correlation of different segmental measurements with femur length. Materials and Methods: Seventeen articles were selected from PubMed, Google Scholar and other public research sharing sites. Articles with coefficients of correlation of segmental measurements with the total length of the femur were included in the study. Results and Discussion: Among the 17 articles, two were related to measurement of the proximal part of the femur only, one was concerned with femoral shaft measurement only, 7 focus on the distal part only, 3 concerned both proximal and distal parts, and 4 articles included all parts of the femur. Sample sizes varied from 50 to 2388 femur bones. The value of the coefficient of correlation (' $r$ ') was found to vary with respect to gender and nationality. The value of ' $r$ ' for several width measurements of the segments had a higher correlation among females compared to male individuals. Conclusion: Though segment 1 of the proximal part, segment 3 of the shaft, and the epicondylar and bicondylar breadths of the distal part of the femur are highly correlated with the total length of femur, an investigator should also consider of gender, race, ethnicity and environmental factors when choosing the femur segment that has the highest value of ' $r$ '.
\end{abstract}

Keywords: length of femur, coefficient of correlation, shaft of femur, segmental measurements.

\section{Introduction}

Human skeletal remains are important for medico-legal importance by providing relevant information regarding the individual's height which may help in identification of deceased. Along with age, sex and ancestry, height is regarded as one of the 'big four' determinations of forensic anthropology that define the biological profile of a person (SWANSON, CHAMELIN, TERRITO et al., 1850). One of the tasks generally given to the forensic anthropologist, in cases with of availability of full or partial skeletons, is to calculate the stature of the individual on the basis of the skeletal remains (FITZPATRICK, 2012). In addition to the use of stature in defining different population groups, it is used to narrow down the many possible identities of the concerned victim. Stature estimation also has importance for assessing health status, sexual dimorphism and body size estimation (HAUSER, SMOLIŃSKI and GOS, 2005).

In addition to body proportions, different skeletal components are used to estimate the stature of the individual, including the lengths of the long bones, lengths of the bodies of the vertebrae, length of the sternum and many more (KLE..., 2012; RYAN and BIDMOS, 2007; SHULIN and FANGWU, 1983; UDHAYA, DEVI and SRIDHAR, 2011). According to Trotter and Glesser stature estimation from long bones is not new, it has been used since the age of Rollet (1888) and remains as current topic of interest for researchers (TROTTER and GLESER, 1952). Significant contributions to the field of estimation of stature from the measurement of the long bones was carried out by Pan $\mathrm{N}$ in Indian population, by Steel and McKern among prehistoric Indian skeletal remains, by Trotter and Glesser among American whites and Negros, and by Wu L among the Chinese population (PAN, 1924; STEELE and MCKERN, 1969; TROTTER and GLESER, 1958; WU, 1989). More accurate estimation of stature can be done from the lengths of long bones of the body. Among the long bones, the femur is the optimal choice for estimating the stature of an individual (STEELE and MCKERN, 1969). In different circumstances, such as vehicle accidents, airplane crashes, casualties of war crimes, animal attacks and natural disasters such as earthquake, it is not uncommon to find only parts of long bones, such as a fragment of a femur rather than a whole intact bone. Grossly mutilated skeletal remains have always been a challenge for the forensic anthropologist and the physical anthropologist. In these circumstances, the investigator has to choose one of the fragments of the long bone to use for estimating the total length of the bone, and then the total length of the bone is further used to estimate the stature of the individual (FITZPATRICK, 2012). This approach is referred to as the indirect method of stature estimation from the fragments of long bones. In contrast, direct method uses the length of the fragment of a long bone to estimate the stature of the individual, without estimating its total length as in the indirect method (AUERBACH, 2011). These two methods were studied in detail by D. Gentry Steel and later by Trotter and Glesser. In the context of extra time and extra steps, 
the direct method has advantages over the indirect method; however, the indirect method is still widely used for estimating the stature of the individual (STEELE and MCKERN, 1969; TROTTER and GLESER, 1958).

Coefficients of correlation measure the strength of an association between two different variables. The Pearson correlation coefficient is the most commonly used correlation coefficient, and measures the strength of the linear association between variables. Its value ranges from -1 to +1 ; higher value is interpreted as a stronger association between the two variables. The positive value denotes that if one variable increases, the other also increases. The Pearson correlation coefficient is generally denoted as - ' $r$ ' (RUMMEL, 1976).

Due to higher coefficients of correlation of the length of the femur bone (among long bones) with living stature, the femur is the optimal bone for estimating the stature of the individual. Since the femur is one of the most frequently preserved bone in the skeleton, it is common to have part of the femur available for investigation in various medico-legal cases (OTAĞ, OTAĞ, AKKOYUN et al., 2016). In cases with availability of fragments of the femur bone only, it is the responsibility of investigators to estimate the total length of the femur bone from the available fragments. Various research has been done to estimate the total length of femur bones from different segmental measurements, including neck length, intertrochanteric crest length, length of different parts of the shaft, bicondylar breadth and length of the linea aspera, among others (BIDMOS, 2008b; SOLAN and KULKARNI, 2013). In cases with availability of different segments of femur bones, the preferred segment of choice depends upon its correlation coefficient with the total femoral length. Fragments with higher values of ' $r$ ' should be regarded as a better choice for estimation of the total length of the femur bone. Though various studies performed among different ethnic groups have provided a method for estimation of femoral length, no concrete review has been performed to determine out the correlation of different segmental measurements with the total femoral length, which might be used to choose the most reliable fragment for estimating the total length more accurately.

\section{Materials and Methods}

This systematic review was performed after registering this topic of review and summary of the protocol to be followed to PROSPERO with the following registration number: CRD42016036489. A summary of the protocol has also been made (KHANAL, SHAH, KOIRALA et al., 2016).

\subsection{Eligibility criteria}

1. Without considering the date of publication, published articles in the English language were considered for review;

2.Articles considering the disarticulated femur bones of adult humans only, with or without identified sex;

3. Articles undertaking different segmental measurements of the femur and their correlation coefficients with maximum length of femur bones;

4. Articles performing measurements manually by the use of measuring instruments such as an osteometric board, Vernier caliper and measuring tape, and not by any other methods including radiography and ultrasonography.
The following types of articles were not included in the study.

1.Articles considering the measurements of femurs subcutaneously;

2. Articles having measurements of angle, shape and weight only;

3. Articles applying methods other rather than manual methods, such as radiographic measurements, neural network methods and ultrasonography.

\subsection{Information sources}

PubMed and Google Scholar were considered the main sources of information. In addition, various individual journals and the web site 'Research Gate' were also consulted. Articles requiring a subscription were accessed by HINARI to retrieve the full article.

\subsection{Search strategy}

A PRISMA format for our search strategy was used to select research papers. PubMed was used by utilizing Mesh terms (Femur/ anatomy and histology, Adult, Regression analysis and Anthropometry). The search was further extended by using the link: "related articles". Google Scholar was used to search by using key terms (total length of femur, segments of femur, cadaver, physical anthropometry, anatomy, forensic anthropology and physical anthropometry). The search was further extended by following the links: "related articles" and "cited by". To include more literature, related journal home pages and public research sharing sites such as "Research Gate" were also searched. Details of the search strategy are shown in Figure 1.

\subsection{Study selection}

Large numbers of identified studies were sequentially excluded if they did not meet the inclusion criteria. Research studies were initially screened on the basis of titles and abstracts. If judgment for selection could not be made, only then was the full text articles reviewed.

\subsection{Data extraction process}

Reviewers extracted relevant raw data from each study via a "data extraction sheet". Data extraction was duplicated by another author independently to reduce bias and mistakes. Any discrepancies found were resolved by discussion among the authors.

\subsection{Data items}

The following information from each included study was extracted.

1. Source of dry femur bone;

2. Sex (if identified);

3. Side (if identified);

4. Race and ethnicity (if identified);

5. Landmarks used for identifying femoral segments;

6. Coefficient of correlation of femoral segments with total femoral length. 


\subsection{Risk of bias in individual studies}

Individual studies were checked meticulously for adequacy of methodological characteristics to ascertain their validity. The methodological characteristics checked included the: method of osteometric measurements, age group of sample specimen and variables measured in each study.

\subsection{Summary measure}

The primary outcome measure was correlation coefficient of segmental measurements with the total femoral length. The value of the coefficient was compared between genders and among different population groups.

\section{Results}

Among 144 initially identified articles, seventeen articles chosen for the review were found to use similar methodologies of measurement, i.e., osteometric board, measuring tape and Vernier caliper. The operational definitions of the common segmental measurements measured and correlated with the maximum femoral length are described in Table 1. For the purpose of description, abbreviations for each segmental measurement are written in parentheses and are additinally used elsewhere when describing these measurements.

Among the 17 articles, two were related to measurement of the proximal part of the femur only, one used shaft measurement

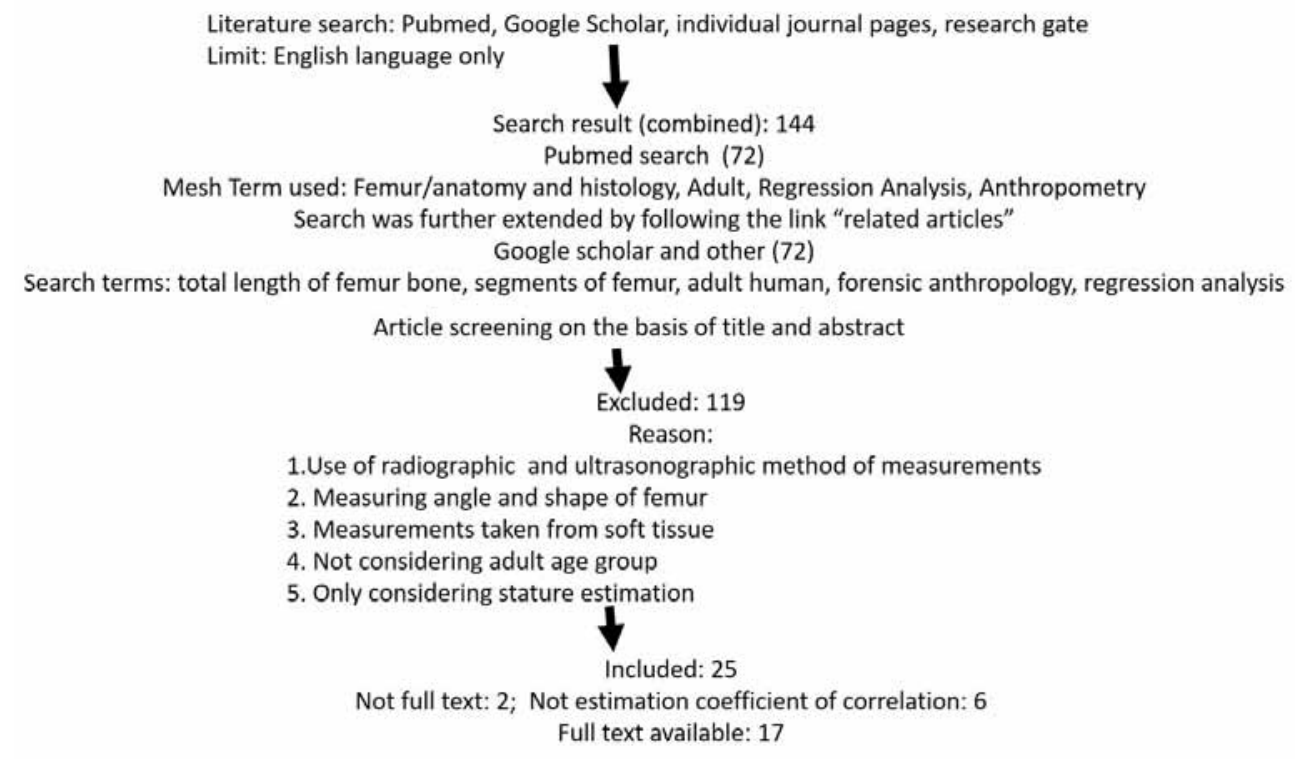

Figure 1. Search strategy using PRISMA format.

Table 1. Operational definitions of the femoral measurements measured in the articles under review.

\begin{tabular}{|c|c|}
\hline Segmental measurement & Operational definition \\
\hline Maximum femoral length (MFL) & $\begin{array}{l}\text { Distance from the most proximal point of the head of the femur to the most distal } \\
\text { point of the medial condyle. }\end{array}$ \\
\hline Intertrochanteric crest length (ITC) & $\begin{array}{l}\text { Distance from the most proximal point of the greater trochanter to the lowest } \\
\text { point of the lesser trochanter. }\end{array}$ \\
\hline Neck length (NL) & $\begin{array}{l}\text { Distance between the base of the head and the intertrochanteric line at the junction } \\
\text { of the back of the neck with the shaft. }\end{array}$ \\
\hline Segment $1(\operatorname{Seg} 1)$ & Distance from the head of the femur to the lesser trochanter. \\
\hline Segment $2(\operatorname{Seg} 2)$ & $\begin{array}{l}\text { Distance from the lesser trochanter to the point where the spiral line and gluteal } \\
\text { line join to form the linea aspera. }\end{array}$ \\
\hline Segment 3 (Seg3) & Distance of the linea aspera \\
\hline Segment 4 (Seg4) & $\begin{array}{l}\text { Distance from the point of division of the linea aspera to the proximal point of the } \\
\text { intercondylar fossa. }\end{array}$ \\
\hline Epicondylar breadth (ECB) & $\begin{array}{l}\text { The linear distance between the medial and the lateral epicondyles of the femur. } \\
\text { This measurement is taken at a right angle to the shaft axis. }\end{array}$ \\
\hline Bicondylar breadth (BCB) & The maximum distance across the femoral condyles in the transverse plane. \\
\hline Medial condylar length (MCL) & $\begin{array}{l}\text { The linear distance between the most anterior and the most posterior points on the } \\
\text { medial condyle. }\end{array}$ \\
\hline Lateral condylar length (LCL) & The linear distance of the lateral condyle measured in an antero-posterior direction. \\
\hline Segment 5 & $\begin{array}{l}\text { Distance from the proximal point of the intercondylar fossa to the most distal point } \\
\text { of the medial condyle. }\end{array}$ \\
\hline
\end{tabular}


only 7 measured the distal part only, 3 utilized both proximal and distal parts, and 4 articles utilized all parts of the femur. Sample sizes varied from 50 to 2388 femur bones. Most of the studies (nine) were performed among Indian populations, followed by Europeans (three), Americans (two), Africans (two) and Koreans (one). Except for three research articles performed among Indian groups, all the articles included measurement that defined gender. Only seven articles defined the side of the femora as right or left (Table 2).

The segmental measurements measured in the articles from the proximal part of the femur included the intertrochanteric crest length (ITC), neck length (NL) and segment l (Segl). Eleven articles were found to have correlation coefficient of proximal segmental measurements with the maximum femoral length (MFL). The common segmental measurements measured from the shaft included segment 2 (Seg2), segment 3 (Seg3) and segment 4 (Seg4). Six of the articles reviewed were found to have the correlations of segmental measurements of the shaft with the MFL. Six segmental measurements, including epicondylar breadth (ECB), bicondylar breadth (BCB), medial condylar length (MCL), lateral condylar length (LCL) and segment 5 (Seg5), were most commonly measured from the distal part of the femur (Table 3 ).

Among the proximal segmental measurements, values of ' $r$ ' for ITC ranged from 0.200 to 0.607 with the MFL, which ranged from 41.91 to $44.45 \mathrm{~cm}$. The value of ' $\mathrm{r}$ ' was highest for Indian men from Bhopal and lowest for Europeans. For the neck length, the correlation was highest among the south Indian men of Tamil Nadu (' $r$ ' $=0.470)$ and lowest for south Indian women (' $r$ ' $=0.290)$. the value of ' $r$ ' for segment 1 ranged from 0.380 to 0.758 , and the correlation was highest for Europeans and lowest for American women. For the measurements of the shaft, only one article showed a value of ' $r$ ' with MFL among Americans ( 0.11 for male and 0.24 for female idividuals), and a combined value was 0.29 . For segment 3 , the value of ' $r$ ' ranged from 0.480 to 0.810 with high correlation among Indians from West Bengal and low correlation among European women and Americans. For segment 4 , the value of ' $r$ ' was very low among European men (0.002) and higher in American women (0.47). Values of

Table 2. Overview of reviewed articles.

\begin{tabular}{|c|c|c|c|c|c|c|c|c|}
\hline Sample population & $\begin{array}{c}\text { Sample } \\
\text { size }\end{array}$ & $\begin{array}{l}\text { Gender } \\
\text { defined }\end{array}$ & $\mathbf{M}$ & $\mathbf{F}$ & $\begin{array}{c}\text { Side } \\
\text { defined }\end{array}$ & $\mathbf{R}$ & $\mathrm{L}$ & $\begin{array}{l}\text { Measured } \\
\text { segments }\end{array}$ \\
\hline Spanish & 130 & Yes & 80 & 50 & No & - & - & All parts \\
\hline West Bengali & 65 & Yes & 65 & - & Yes & 23 & 42 & Distal \\
\hline Maya & 100 & Yes & 68 & 32 & No & - & - & All parts \\
\hline Portuguese & 200 & Yes & 100 & 100 & No & - & - & Proximal + Distal \\
\hline West Bengali & 148 & $\mathrm{No}$ & - & - & Yes & 85 & 63 & Shaft \\
\hline Indian & 128 & Yes & - & - & No & - & - & Distal \\
\hline ISA & 100 & Yes & 50 & 50 & $\mathrm{No}$ & - & - & Distal \\
\hline SAED & 100 & Yes & 50 & 50 & No & - & - & Distal \\
\hline American & 2388 & Yes & 1310 & 1078 & No & - & - & Distal \\
\hline South Indian & 60 & Yes & 60 & - & No & - & - & Distal \\
\hline Tamil Nadu & 171 & Yes & 94 & 77 & Yes & 83 & 88 & Proximal \\
\hline European & 59 & Yes & 33 & 26 & No & - & - & All parts \\
\hline Korean & 195 & Yes & 120 & 75 & Yes & - & - & Distal \\
\hline Bhopal (Indian) & 200 & No & - & - & No & - & - & Proximal \\
\hline Rajasthan (Indian) & 50 & No & - & - & Yes & 27 & 23 & Proximal + Distal \\
\hline Bhopal (Indian) & 288 & Yes & 164 & 124 & Yes & 144 & 144 & All parts \\
\hline South Indian & 100 & Yes & 50 & 50 & Yes & 100 & - & Proximal + Distal \\
\hline
\end{tabular}

$\mathrm{M}=$ male; $\mathrm{F}=$ female; $\mathrm{R}=$ right side $\mathrm{L}=$ left side; $\mathrm{ISA}=$ indigenous South African; $\mathrm{SAED}=$ South African of European descent.

Table 3. Commonly measured segmental measurements in articles selected for review.

\begin{tabular}{|c|c|c|}
\hline & Segmental measurements & Number of articles \\
\hline \multirow{3}{*}{ Proximal measurements } & Intertrochanteric crest length (ITC) & 5 \\
\hline & Neck length (NL) & 3 \\
\hline & Segment 1 & 3 \\
\hline \multirow{3}{*}{ Shaft measurements } & Segment 2 & 1 \\
\hline & Segment 3 & 3 \\
\hline & Segment 4 & 2 \\
\hline \multirow{5}{*}{ Distal measurements } & Epicondylar breadth (ECB) & 7 \\
\hline & Bicondylar breadth (BCB) & 6 \\
\hline & Medial condylar length (MCL) & 5 \\
\hline & Lateral condylar length (LCL) & 5 \\
\hline & Segment 5 & 3 \\
\hline
\end{tabular}


' $r$ ' for segmental measurements of the proximal end and shaft of the femur in different populations are presented in Table 4.

Table 5 shows the correlation coefficient value $(r)$ with the MFL among different populations. ECB, BCB, MCL, LCL and Seg5 were the most common segmental measurements measured at the distal end of the femur. For the ECB, values of ' $r$ ' ranged from 0.40 to 0.93 and were highest for Indians and lowest for men in the South African of European descent (SAED) population. For BCB, values of ' $r$ ' were found to be highest among Americans (0.998) and lowest for Indian women from Delhi $(0.300)$. The lengths of medial and distal condyles had values of ' $r$ ' highest among Indians and lowest among SAED individuals. Values of ' $r$ ' for MCL ranged from 0.33 to 0.92 , and for LCL ranged from 0.54 to 0.86 . Correlation of Seg 5 was found to be lowest among Americans (0.45) and highest among Europeans (0.599).

\section{Discussion}

As the soft tissues often cannot contribute much to the identification process, skeletal components are an important tool for human identification because they are resistant to heat and degradative processes. The femur is one of the long bones used for estimation of 'stature of the individual', which is one of the big four determinations of forensic anthropology. Length of the femur could be used to estimate the stature by one of the three methods suggested by Bidmos, i.e., l) the anatomical method, 2) the mathematical method and 3) the femur/stature ratio (BIDMOS, 2009). In the anatomical method, an intact femur is required; therefore, the mathematical method is the most commonly used method for stature estimation based on the length of femur when only segments of femurs are available. Stature estimation from fragments of the femur is one of the oldest methods introduced in 1935 by Gertrude Muller (MULLER, 1935). In this method, a fragment of the femur is used to estimate the total length of the femur bone, and then the total length of the femur bone is used to estimate the stature of the individual. This approach is called the indirect method of stature estimation (STEELE and MCKERN, 1969). This study reviewed 17 articles mentioning coefficients of correlation between segmental measurements of the femur and the maximum femoral length. The value of the coefficient of correlation (' $r$ ') allows an investigator to choose optimal fragments of the femur to estimate its total length in cases without an intact femur bone in different scenarios of medico-legal cases. The results of this study may be helpful for forensic anthropologists and archaeologists in different processes of identification.

Different studies have shown that the formula used for the estimation of the total length of the femur from its segmental measurements is population-specific due to an association of the length of the femur with sex, race and environmental factors of specific groups of the populations (TROTTER and

Table 4. Values of coefficients of correlation ( $r$ ) between proximal and shaft measurements of femora with maximum femoral length (MFL).

\begin{tabular}{|c|c|c|c|c|}
\hline & Authors & $\begin{array}{c}\text { Ethnicity } \\
\text { (population) }\end{array}$ & Value of $\mathbf{r}$ & MFL (in cm) \\
\hline \multirow{5}{*}{ ITC } & Gidna and Domínguez-Rodrigo (2013) & European & 0.200 & \\
\hline & Singh, Nair, Anjankar et al. (2013) & Indian (Bhopal) & 0.596 & 43.26 \\
\hline & Parmar, Shah, Goda et al. (2015) & Indian (Rajasthan) & $0.550(\mathrm{Rt}) ; 0.210(\mathrm{Lt})$ & $43.24(\mathrm{Rt}) ; 44.45(\mathrm{Lt})$ \\
\hline & Nath and Prabha (1999) & Indian (Bhopal) & $0.607(\mathrm{M}) ; 0.610(\mathrm{~F})$ & $43.96(\mathrm{M}) ; 41.91(\mathrm{~F})$ \\
\hline & Umesh Babu, Sadashiv and Kiran (2013) & South Indian & $0.321(\mathrm{M}) ; 0.290(\mathrm{~F})$ & \\
\hline \multirow{3}{*}{ NL } & Umesh Babu, Sadashiv and Kiran (2013) & South Indian & $0.330(\mathrm{M}) ; 0.455(\mathrm{~F})$ & \\
\hline & Nath and Prabha (1999) & Indian (Bhopal) & $0.318(\mathrm{M}) ; 0.413(\mathrm{~F})$ & $43.96(\mathrm{M}) ; 41.91(\mathrm{~F})$ \\
\hline & Prasad, Vettivel, Jeyaseelan et al. (1996) & Indian (Tamil Nadu) & 0.470 & $\begin{array}{c}43.47 \\
44.86(\mathrm{M}) ; 41.80(\mathrm{~F})\end{array}$ \\
\hline \multirow{3}{*}{ Segl } & Wright and Vásquez (2003) & American & $\begin{array}{c}0.630 \\
0.38(\mathrm{M}) ; 0.68(\mathrm{~F}) \\
\end{array}$ & \\
\hline & Mendonça (2000) & $\begin{array}{c}\text { European } \\
\text { (Portuguese) }\end{array}$ & 0.620 & 43.15 \\
\hline & Jacobs (1992) & European & $\begin{array}{c}0.758 \\
0.725(\mathrm{M}) ; 0.655(\mathrm{~F})\end{array}$ & $\begin{array}{c}44.39 \\
45.74(\mathrm{M}) ; 42.18(\mathrm{~F})\end{array}$ \\
\hline Seg2 & Wright and Vásquez (2003) & American & $\begin{array}{c}0.29 \\
0.11(\mathrm{M}) ; 0.24(\mathrm{~F})\end{array}$ & \\
\hline \multirow{3}{*}{$\operatorname{Seg} 3$} & Wright and Vásquez (2003) & American & $\begin{array}{c}0.52 \\
0.53(\mathrm{M}) ; 0.56(\mathrm{~F}) \\
\end{array}$ & \\
\hline & Gidna and Domínguez-Rodrigo (2013) & European (Spanish) & $\begin{array}{c}0.66(\mathrm{M}) \\
0.48(\mathrm{~F}) \\
\end{array}$ & \\
\hline & Ghosh, Konar, Mondal et al. (2015) & Indian (West Bengal) & 0.81 & \\
\hline \multirow{2}{*}{$\operatorname{Seg} 4$} & Wright and Vásquez (2003) & American & $\begin{array}{c}0.31 \\
0.24(\mathrm{M}) ; 0.47(\mathrm{~F})\end{array}$ & \\
\hline & Jacobs $(1992)$ & European & $\begin{array}{c}0.134 \\
0.002(\mathrm{M}) ; 0.238(\mathrm{~F})\end{array}$ & $\begin{array}{c}44.39 \\
45.74(\mathrm{M}) ; 42.18(\mathrm{~F})\end{array}$ \\
\hline
\end{tabular}

$\mathrm{Rt}=$ right; $\mathrm{Lt}=$ left; $\mathrm{M}=$ male; $\mathrm{F}=$ female; $\mathrm{ITC}=$ intertrochanteric crest length; $\mathrm{NL}=$ neck length. 
Table 5. Values of coefficients of correlation ( $r$ ) between of distal end measurements of femora with the maximum femoral length (MFL).

\begin{tabular}{|c|c|c|c|c|c|c|c|}
\hline \multirow{2}{*}{ Articles } & \multirow{2}{*}{$\begin{array}{c}\text { Ethnicity } \\
\text { (Population) }\end{array}$} & \multirow{2}{*}{ MFL } & \multicolumn{5}{|c|}{ Value of ' $r$ ' } \\
\hline & & & ECB & BCB & MCL & LCL & Seg5 \\
\hline $\begin{array}{l}\text { Mukhopadhyay, } \\
\text { Ghosh and Dan } \\
(2010)\end{array}$ & $\begin{array}{l}\text { Indian (West } \\
\text { Bengal) }\end{array}$ & $41.82(\mathrm{M})$ & 0.85 & & & & \\
\hline $\begin{array}{l}\text { Thejaswi, Murari, } \\
\text { Kumar et al. (2014) }\end{array}$ & $\begin{array}{l}\text { Indian } \\
\text { (Delhi) }\end{array}$ & & $\begin{array}{c}0.93 \\
0.88(\mathrm{M}) \\
0.44(\mathrm{~F})\end{array}$ & $\begin{array}{c}0.89 \\
0.85(\mathrm{M}) \\
0.30(\mathrm{~F})\end{array}$ & $\begin{array}{c}0.92 \\
0.87(\mathrm{M}) \\
0.33(\mathrm{~F})\end{array}$ & $\begin{array}{c}0.86 \\
0.86(\mathrm{M}) \\
0.86(\mathrm{~F})\end{array}$ & \\
\hline Bidmos (2008a) & $\begin{array}{l}\text { Indigenous } \\
\text { South African }\end{array}$ & $\begin{array}{l}45.46(\mathrm{M}) \\
42.86(\mathrm{~F})\end{array}$ & $\begin{array}{c}0.52(\mathrm{M}) \\
0.75(\mathrm{~F})\end{array}$ & $\begin{array}{c}0.53(\mathrm{M}) \\
0.72(\mathrm{~F})\end{array}$ & $\begin{array}{c}0.71(\mathrm{M}) \\
0.62(\mathrm{~F})\end{array}$ & $\begin{array}{c}0.63(\mathrm{M}) \\
0.71(\mathrm{~F})\end{array}$ & \\
\hline Bidmos (2008b) & SAED & $\begin{array}{l}46.52(\mathrm{M}) \\
43.38(\mathrm{~F})\end{array}$ & $\begin{array}{c}0.40(\mathrm{M}) \\
0.72(\mathrm{~F})\end{array}$ & $\begin{array}{c}0.46(\mathrm{M}) \\
0.78(\mathrm{~F})\end{array}$ & $\begin{array}{l}0.43(\mathrm{M}) \\
0.72(\mathrm{~F})\end{array}$ & $\begin{array}{c}0.54(\mathrm{M}) \\
0.75(\mathrm{~F})\end{array}$ & \\
\hline Auerbach (2011) & American & & & 0.998 & & & \\
\hline $\begin{array}{l}\text { Chandran and } \\
\text { Kumar }(2012)\end{array}$ & South Indian & $44.9(\mathrm{M})$ & $0.81(\mathrm{M})$ & $0.77(\mathrm{M})$ & $0.81(\mathrm{M})$ & $0.79(\mathrm{M})$ & \\
\hline $\begin{array}{l}\text { Lee, Kim, Kwak et } \\
\text { al. }(2005)\end{array}$ & Korean & & $\begin{array}{c}0.815 \\
0.71(\mathrm{M}) \\
0.74(\mathrm{~F})\end{array}$ & & & & \\
\hline $\begin{array}{l}\text { Umesh Babu, } \\
\text { Sadashiv and Kiran } \\
(2013)\end{array}$ & South Indian & & $\begin{array}{l}0.661(\mathrm{M}) \\
0.705(\mathrm{~F})\end{array}$ & & $\begin{array}{l}0.507 \mathrm{M}) \\
0.513(\mathrm{~F})\end{array}$ & $\begin{array}{l}0.578(\mathrm{M}) \\
0.644(\mathrm{~F})\end{array}$ & \\
\hline $\begin{array}{l}\text { Wright and Vásquez } \\
(2003)\end{array}$ & American & & & & & & $\begin{array}{c}0.45 \\
0.22(\mathrm{M}) \\
0.27(\mathrm{~F}) \\
\end{array}$ \\
\hline Mendonça (2000) & $\begin{array}{c}\text { European } \\
\text { (Portuguese) }\end{array}$ & & & & & & 0.60 \\
\hline Jacobs (1992) & European & & & & & & $\begin{array}{c}0.599 \\
0.412(\mathrm{M}) \\
0.770(\mathrm{~F})\end{array}$ \\
\hline
\end{tabular}

$\mathrm{M}=$ male $\mathrm{F}=$ female $\mathrm{MFL}=$ maximum femoral length $\mathrm{ECB}=$ Epicondylar breadth $\mathrm{BCB}=$ bicondylar breadth; $\mathrm{MCL}=$ medial $\operatorname{condylar}$ length; LCL = lateral condylar length; Seg $5=$ segment 5 .

GLESER, 1952). There are several different population-specific factors, including secular changes, cultural factors, genetic factors, gender, race and environmental factors. Changes in socioeconomic status has also been found to have an influence in the growth of femur bones in different genders (OKAI, 2010). Among the 17 articles, 9 were performed among Indian populations, 3 among European populations, 2 among American populations, 2 among African populations and 1 in a Korean population. ITC was measured in Indian (NATH and PRABHA, 1999; PARMAR, SHAH, GODA et al., 2015; SINGH, NAIR, ANJANKAR et al., 2013; UMESH BABU, SADASHIV and KIRAN, 2013) and European populations (GIDNA and DOMÍNGUEZ-RODRIGO, 2013), and it was higher in Indian populations (0.21-0.67) compared to European populations $(0.20)$. If compared between male and female individuals, the values of ' $r$ ' for ITC were approximately similar. The value of ' $r$ ' for NL was also comparable between male and female individuals, with the men having slightly lower values than women (NATH and PRABHA, 1999; UMESH BABU, SADASHIV and KIRAN, 2013). Studies done in Indian populations showed values of ' $r$ ' ranging from
0.318 to 0.330 among men and 0.413 to 0.455 among women. A study done by Prasad R among Indians from Tamil Nadu also showed a similar value of ' $r$ ' for NL (0.47) (PRASAD, VETTIVEL, JEYASEELAN et al., 1996). When comparing values of ' $r$ ' for Segl, they were higher in European femora (0.62 to 0.76$)$ than in Americans (0.38 to 0.68$)$. When compared between two sexes, the values of ' $r$ ' for Segl was higher in femora of American men and European women (MENDONÇA, 2000; JACOBS, 1992; WRIGHT and VÁSQUEZ, 2003). Correlation of Seg2 with MFL was lower (0.29) than that of Segl; when compared between the two sexes, it was higher in women (0.24) than in men (0.11), as shown by a study by Wright $\mathrm{R}$ among femora of Americans (WRIGHT and VÁSQUEZ, 2003). Segment 3 (the length of the linea aspera, which is site of attachment for many muscles of femur) is one of the most common fragments available to forensic anthropologists for examination purposes. The value of ' $r$ ' for Seg3 with the MFL was found to be higher among femora of Indians (0.81) compared to Americans and Europeans. When compared between the two genders, the correlation was stronger in American women and European 
men (GHOSH, KONAR, MONDAL et al., 2015; GIDNA and DOMÍNGUEZ-RODRIGO, 2013; WRIGHT and VÁSQUEZ, 2003). Sex-wise, the value of ' $r$ ' for Seg3 was opposite to that of Segl and was similar to that of Seg2. Segment 4 is the length of the popliteal surface of the femur and had a weak correlation with the MFL (' $r$ ' $=0.31$ in Americans and 0.134 in Europeans). When compare between men and women, Seg3 was more highly correlated among femora of women than in men (JACOBS, 1992; WRIGHT and VÁSQUEZ, 2003).

The distal end of the femur is also used for estimating the total length of femur. Commonly measured segmental measurements from the distal end of the femur include epicondylar breadth, bicondylar breadth, longitudinal distance from the intercondylar fossa to the distal most point of the medial condyle (Seg5), and length of medial and distal condyles. Correlation of Seg 5 was higher in femora of Europeans ( 0.59 to 0.60$)$ compared to Americans. When compared between the sexes, segment 5 had a higher correlation with MFL among women than in men (MENDONÇA, 2000; JACOBS, 1992; WRIGHT and VÁSQUEZ, 2003). ECB was found to have a higher value of ' $\mathrm{r}$ ', which ranged from 0.40 to 0.93 . The correlation was lowest among femora of African origin ( 0.40 to 0.75 ) (BIDMOS, 2008a, 2008b) followed by Korean (0.815) (LEE, KIM, KWAK et al., 2005) and Indian femora (0.81 to 0.93 ) (CHANDRAN and KUMAR, 2012; MUKHOPADHYAY, GHOSH and DAN, 2010; UMESH BABU, SADASHIV and KIRAN, 2013). The correlation was stronger for femora of Korean men and African populations. For Indian populations, a single consensus could not be determined due to variations in results from different studies. A study done among femora of Indian origin by Thejaswi $\mathrm{H}$ $\mathrm{T}$ showed a higher correlation in men while a study by Babu U showed women having higher correlations (THEJASWI, MURARI, KUMAR et al., 2014; UMESH BABU, SADASHIV and KIRAN, 2013). Bicondylar breadth (BCB) also followed at similar pattern as the ECB, with low scores of correlation among femora of African origin (0.46 to 0.78) (BIDMOS, 2008a, b) followed by Indian (0.77 to 0.89) (CHANDRAN and KUMAR, 2012; THEJASWI, MURARI, KUMAR et al., 2014) and American populations (0.998) (AUERBACH, 2011). Sex-wise, BCB of male femora had a higher correlation in Indian populations and of female femora in African populations. The antero-posterior lengths of condyles of the femur was also considered segmental measurements to estimate the MFL in various studies (BIDMOS, 2008a, b; CHANDRAN and KUMAR, 2012; THEJASWI, MURARI, KUMAR et al., 2014; UMESH BABU, SADASHIV and KIRAN, 2013). The values of ' $r$ ' for both MCL and LCL were found to be higher among femora of Indian origin ( 0.51 to 0.92 for MCL and 0.64 to 0.86 for LCL) in comparison to femora of African origin ( 0.43 to 0.72 for MCL and 0.54 to 0.72 for LCL). No conclusion was made regarding whether men or women had higher values of ' $r$ ' due to variations in results of the reviewed studies.

When all the articles were reviewed to determine whether there was any segmental dimension which had a higher correlation with one of the genders, one proximal measurement (NL), one shaft measurement ( $\operatorname{Seg} 4)$ and three distal measurements (Seg5, ECB and LCL) had values of ' $r$ ' higher in femora of women than in men. Other measurements were found to have no conclusive differences when comparing between the two genders. Epicondylar breadth is one of the breadth measurements which defines the sexual dimorphism of the femora. A study done among Korean femora showed that almost all the breadth measurements performed had accuracies greater than $80 \%$ in defining the sex of the individual. The same study also mentioned that ECB was the most valuable measurement for determining sex (LEE, KIM, JEONG et al., 2014). These results could not be explained based on solid evidence, but they might be due to different patterns of growth between male and female fetuses. These sex-specific growth patterns could underlie the different forms of growth in various segmental levels of femora (MELAMED, MEIZNER, MASHIACH et al., 2013). There is also evidence of functional differences of femora between the two genders. Femur of male bears more stress than those of female due to the heavier body weights of male. Female femora are modified with respect to specialized functions of reproduction (OKAI, 2010).

\section{Conclusion}

Due to the high degree of correlation of the femur with the stature of individuals, and due to its role as one of the long bones most commonly retrieved from different medico-legal cases, femur is the optimal choice for estimating the stature of the individual. Total length of the femur can be estimated through the use of regression equations from segmental measurements of the proximal end, shaft and distal end of femora. From a review of 17 articles mentioning the correlation of segmental measurement of the femur with its MFL, it was found that ITC, NL and Segl were the most common segmental measurements of the proximal end of the femur; Seg2, Seg3 and Seg 4 were the most common segmental measurements from the shaft of the femur; and Seg5, ECB, BCB, MCL and LCL were the most common segmental measurements from the distal end of the femur. When the values of correlation coefficient (' $r$ ') was compared among different segmental measurements, it was found to vary with respect to different populations and with the gender of the individual. When considering the discrete value of ' $r$ ', it was highest for Seg 1 in the proximal part of femur, Seg 3 in the shaft of the femur and $\mathrm{ECB}$ and $\mathrm{BCB}$ in the distal part of the femur. When choosing the segment of the femur to estimate the stature of the individual, population-specific values of ' $r$ ' should be taken into consideration by investigators so that an accurate estimation of MFL and ultimately stature can be estimated.

Acknowledgements: The authors wish to acknowledge the librarian Mr. Binod Yadav for helping to access full text articles and Dr. Prakash Baral for advicing for various aspects of manuscript preparation.

\section{Conflict of interest}

The authors declare that they have no conflict of interest.

\section{References}

AUERBACH, BM. Methods for estimating missing human skeletal element osteometric dimensions employed in the revised fully technique for estimating stature. American Journal of Physical Anthropology, 2011, vol. 145, n. 1, p. 67-80. PMid:21337315. http://dx.doi. org/10.1002/ajpa.21469.

BIDMOS, MA. Estimation of stature using fragmentary femora in indigenous South Africans. International Journal of Legal Medicine, 
2008a, vol. 122, n. 4, p. 293-299. PMid:17901969. http://dx.doi. org/10.1007/s00414-007-0206-2.

BIDMOS, MA. Stature reconstruction using fragmentary femora in South Africans of European descent. Journal of Forensic Sciences, 2008b, vol. 53, n. 5, p. 1044-1048. PMid:18636977. http://dx.doi. org/10.1111/j.1556-4029.2008.00808.x.

BIDMOS, MA. Soft tissue evaluation as a correction factor for stature estimation. Johannesburg: University of the Witwatersrand, 2009.

CHANDRAN, M. and KUMAR, V. Reconstruction of femur length from its fragments in South Indian males. Journal of Forensic and Legal Medicine, 2012, vol. 19, n. 3, p. 132-136. PMid:22390998. http://dx.doi.org/10.1016/j.jflm.2011.12.010.

FITZPATRICK, TA. Analysis of secular change and a novel method of stature estimation utilizing modern skeletal collections. Georgia: Georgia State University, 2012.

GHOSH, T., KONAR, S., MONDAL, MK., SINGHA, KB., DEY, A. and DAS, J. Estimation of stature from fragment of femur (popliteal length) in bengali population. International Journal of Anatomy and Research, 2015, vol. 3, n. 3, p. 1245-1248. http://dx.doi. org/10.16965/ijar.2015.202.

GIDNA, AO. and DOMÍNGUEZ-RODRIGO, MA. Method for reconstructing human femoral length from fragmented shaft specimens. Journal of Comparative Human Biology., 2013, vol. 64, n. 1, p. 29-41. PMid:23218649. http://dx.doi.org/10.1016/j.jchb.2012.09.006.

HAUSER, R., SMOLIŃSKI, J. and GOS, T. The estimation of stature on the basis of measurements of the femur. Forensic Science International, 2005, vol. 147, n. 2-3, p. 185-190. PMid:15567625. http://dx.doi.org/10.1016/j.forsciint.2004.09.070.

JACOBS, K. Estimating femur and tibia length from fragmentary bones: an evaluation of Steele's (1970) method using a prehistoric European sample. American Journal of Physical Anthropology, 1992, vol. 89, n. 3, p. 333-345. PMid:1485641. http://dx.doi.org/10.1002/ ajpa.1330890307.

KHANAL, L., SHAH, S., KOIRALA, S. and BARAL, P. Exploration of correlation coefficient of different segmental measurements with total length of disarticulated femur bones: systematic review. York: University of York, 2016. PROSPERO 2016:CRD42016036489. Available from: <http://www.crd.york.ac.uk/PROSPERO/display_record. asp?ID=CRD42016036489 >. Access in: 19 may 2016.

KLE UNIVERSITY. Assessment of stature using odontometry, facial and skull anthropometry among the students and staff of KLE VK institute of dental sciences, belgaum: a comparative study. India: Kle University, 2012. Registration n ${ }^{\circ}$ IH0209001.

LEE, HJ., KIM, DI., KWAK, SD., LEE, YU., KIM, SY., PARK, KD., HAN, KH. and HAN, SH. Estimation of maximum femoral length from fragmentary femur. Korean Journal of Physical Anthropology, 2005, vol. 18, n. 3, p. 247-254. http://dx.doi.org/10.11637/ kjpa.2005.18.4.247.

LEE, JH., KIM, YS., JEONG, YG., LEE, NS., HAN, SY., TUBBS, RS. and HAN, SH. Sex determination from partial segments and maximum femur lengths in Koreans using computed tomography. Folia Morphologica, 2014, vol. 73, n. 3, p. 353-358. PMid:25242249. http://dx.doi.org/10.5603/FM.2014.0052.

MELAMED, N., MEIZNER, I., MASHIACH, R., WIZNITZER, A., GLEZERMAN, M. and YOGEV, Y. Fetal sex and intrauterine growth patterns. Journal of Ultrasound in Medicine, 2013, vol. 32, n. 1, p. 35-43. PMid:23269708. http://dx.doi.org/10.7863/ jum.2013.32.1.35.

MENDONÇA, MC. Estimation of height from the length of long bones in a Portuguese adult population. American Journal of Physical Anthropology, 2000, vol. 112, n. 1, p. 39-48. PMid:10766942. http:// dx.doi.org/10.1002/(SICI)1096-8644(200005)112:1<39::AIDAJPA5 $>3.0 . C O ; 2-\#$.
MUKHOPADHYAY, PP., GHOSH, TK. and DAN, U. Correlation between maximum femoral length and epicondylar breadth and its application in stature estimation: a population specific study in Indian Bengali males. J indian acad forensic med, 2010, vol. 32, n. 3, p. 971-974.

MULLER, G. Zur bestimmung der Lange beschadigter extremitatenknochen. Anthropologischer Anzeiger, 1935, vol. 12, p. 70-72.

NATH, S. and PRABHA, B. Estimation of femoral length through fragmentary bone dimensions. Journal of Human Ecology, 1999, vol. 10, n. 2, p. 137-141.

OKAI, I. Osteometric assessment of bones of ghanaian males. Gana: Kwame Nkrumah University of Science and Technology, 2010.

OTAĞ, İ., OTAĞ, A., AKKOYUN, S. and ÇIMEN, M. Estimation of the femur length from its proximal measurements in Anatolian Caucasians by artificial neural networks. The Australian Journal of Forensic Sciences, 2016, vol. 48, n. 3, p. 279-286. http://dx.doi.or $\mathrm{g} / 10.1080 / 00450618.2015 .1004193$.

PAN, N. Length of long bones and their proportion to body height in Hindus. Journal of Anatomy, 1924, vol. 58, n. 4, p. 374-378. PMid:17104032.

PARMAR, AM., SHAH, KP., GODA, J., AGHERA, B. and AGARWAL, GC. Reconstruction of total length of femur from its proximal and distal fragments. International Journal of Anatomy and Research, 2015 , vol. 3, n. 4, p. 1665-1668. http://dx.doi.org/10.16965/ ijar.2015.310.

PRASAD, R., VETTIVEL, S., JEYASEELAN, L., ISAAC, B. and CHANDI, G. Reconstruction of femur length frm markers ot its proximal end. Clinical Anatomy, 1996, vol. 9, n. 1, p. 28-33. PMid:8838277. http://dx.doi.org/10.1002/(SICI)1098-2353(1996)9:1<28::AID$\mathrm{CA6}>3.0 . \mathrm{CO} ; 2-\mathrm{W}$.

RUMMEL, R. Understanding correlation. Honolulu: Department of Political Science, University of Hawaii, 1976. Available from: <http:// www.hawaii.edu/powerkills/UC.HTM>. Access in: 19 may 2016.

RYAN, I. and BIDMOS, MA. Skeletal height reconstruction from measurements of the skull in indigenous South Africans. Forensic Science International, 2007, vol. 167, n. 1, p. 16-21. PMid:16842949. http://dx.doi.org/10.1016/j.forsciint.2006.06.003.

SHULIN, P. and FANGWU, Z. Estimation of stature from skull, clavicle, scapula and os coxa of male adult of southern chinese. Acta Anthropologica Sinica, 1983, vol. 2, p. 253-259.

SINGH, S., NAIR, S.K., ANJANKAR, V., BANKWAR, V. and SATPATHY, DK. Regression equation for estimation of femur length in Central Indians from inter-trochanteric crest. Journal of Indian Academy of Forensic Medicine, 2013, vol. 35, n. 3, p. 223-226.

SOLAN, S. and KULKARNI, R. Estimation of total Length of Femur From Its Fragments in South Indian Population. Journal of Clinical and Diagnostic Research : JCDR, 2013, vol. 7, n. 10, p. 2111-2115. http://dx.doi.org/10.7860/JCDR/2013/6275.3465. PMid:24298451.

STEELE, DG. and MCKERN, TW. A method for assessment of maximum long bone length and living stature from fragmentary long bones. American Journal of Physical Anthropology, 1969, vol. 31, n. 2, p. 215-227. PMid:5348797. http://dx.doi.org/10.1002/ ajpa.1330310211.

SWANSON, C., CHAMELIN, N., TERRITO, L. and TAYLOR, $\mathrm{R}$. The evolution of criminal investigation and forensic science. In SWANSON, C., CHAMELIN, N., TERRITO, L. and TAYLOR, R. Criminal investigation. 11th ed. New York: McGraw-Hill, 1850. p. 2-16.

THEJASWI, H., MURARI, A., KUMAR, A. and KRISHNA, K. Estimation of the length of femur from its distal fragments. Indian 
KHANAL, L., SHAH, S. and KOIRALA, S.

Journal of Forensic Medicine and Toxicology, 2014, vol. 8, n. 1, p. 195-201. http://dx.doi.org/10.5958/j.0973-9130.8.1.042.

TROTTER, M. and GLESER, GC. A re-evaluation of estimation of stature based on measurements of stature taken during life and of long bones after death. American Journal of Physical Anthropology, 1958, vol. 16, n. 1, p. 79-123. PMid:13571400. http://dx.doi. org/10.1002/ajpa.1330160106.

TROTTER, M. and GLESER, GC. Estimation of stature from long bones of American Whites and Negroes. American Journal of Physical Anthropology, 1952, vol. 10, n. 4, p. 463-514. PMid:13007782. http://dx.doi.org/10.1002/ajpa.1330100407.

UDHAYA, K., DEVI, K. and SRIDHAR, J. Regression equation for estimation of length of humerus from its segments: a south Indian population study. Journal of Clinical and Diagnostic Research, 2011, vol. 5 , n. 4 , p. $783-786$.
UMESH BABU, R., SADASHIV, R. and KIRAN, J. Reconstruction of femur length from its fragments. Indian Journal of Forensic Medicine and Toxicology, 2013, vol. 7, n. 2, p. 168-171. http://dx.doi.org/1 0.5958/j.0973-9130.7.2.038

WRIGHT, LE. and VÁSQUEZ, MA. Estimating the length of incomplete long bones: forensic standards from Guatemala. American Journal of Physical Anthropology, 2003, vol. 120, n. 3, p. 233-251. PMid:12567377. http://dx.doi.org/10.1002/ajpa.10119.

WU, L. Sex determination of Chinese femur by discriminant function. Journal of Forensic Sciences, 1989, vol. 34, n. 5, p. 1222-1227. PMid:2809546. http://dx.doi.org/10.1520/JFS12756J.

Received May 30, 2016 Accepted June 9, 2017 